\title{
Pematahan Dormansi Benih Kebiul (Caesalphinia bonduc L.) dengan Berbagai Metode
}

\author{
Breaking Seed Dormancy of Caesalpinia bonduc L. with Various Methods
}

\author{
Yesi Uyatmi, Entang Inoriah, Marwanto \\ Program Studi Agroekoteknologi, Fakultas Pertanian, Universitas Bengkulu \\ *: entang.inoriah@yahoo.com
}

\begin{abstract}
Seed of Caesalpinia bonduc L. is difficult to germinate due to the thick and hard seed coat. The research aims to evaluate various methods for breaking dormancy of C. bonduc seed. This study was conducted from December to January 2016 The way to break the dormancy were arranged in Completely Randomized Design. Eleven methods to solve the seed dormancy of C. bonduc were compared. The ways to break the dormancy were soaking in water with different temperatures. The temperatures were $30^{\circ} \mathrm{C}$ for 0 hours, 5 hours, 10 hours, and 15 hours. Other techniques to break the dormancy were soaking in hot water at $100^{\circ} \mathrm{C}$ for 5 hours, 10 hours, and 15 hours. Warm stratification with $100 \%$ air humidity (RH) at $40^{\circ} \mathrm{C}$ for five days, ten days and 15 days also included as treatments. The last method was seed piercing with a needle. The variables observed in this study were germination capacity, germination rate, epicotyl length, plant height, and root length. The results of this study showed that the 11 methods of breaking seed dormancy significantly affected germination capacity, germination rate, emerging epicotyl, and plant height. Seed piercing classified as the most efficient method as indicated by the value of $100 \%$ in germination capacity, 1.43 in germination rate, $13.64 \mathrm{~cm}$ in plant height, and $6.16 \mathrm{~cm}$ in root length.
\end{abstract}

Keywords : seed, Caesalpinia bonduc L., scarification, stratification.

\begin{abstract}
ABSTRAK
Biji kebiul banyak digunakan oleh masyarakat Bengkulu Selatan sebagai obat untuk pengobatan berbagai pernyakit seperti malaria, sakit kepala, kencing manis, batu ginjal dan batu empedu. Benih kebiul ini memiliki kulit yang tebal dan keras sehingga sulit untuk berkecambah. Ada berbagai cara perlakuan pendahuluan yang dapat dilakukan yaitu skrafikasi dan stratifikasi. Penelitian ini dilaksanakan pada bulan Desember 2016 - Januari 2016. Penelitian ini disusun dengan menggunakan Rancangan Acak Lengkap (RAL). Perlakuan yang dilakukan pada penelitian ini diantaranya perendaman dalam air dengan suhu 300C selama 0 jam, $5 \mathrm{jam}, 10 \mathrm{jam}$, dan $15 \mathrm{jam}$. Perendaman dalam air panas dengan suhu $100^{\circ} \mathrm{C}$ selama $5 \mathrm{jam}, 10$ jam, dan 15 jam. Stratifikasi hangat dengan kelembapan udara (RH) $100 \%$ dengan suhu $40^{\circ} \mathrm{C}$ selama 5 hari, 10 hari, dan 15 hari. Variabel yang diamati dalam penelitian ini daya kecambah, kecepatan berkecambah, muncul epikotil, tinggi tanaman, dan panjang akar. Hasil penelitian memberikan pengaruh nyata terhadap variabel daya kecambah, kecepatan berkecambah, muncul epikotil, dan tinggi tanaman. Metode perlakuan pematahan dormansi benih memberikan pengaruh terhadap berbagai variabel yang diuji. Metode perlakuan kulit benih (PD 11) menunjukkan metode terbaik, semua variabel yang diuji yaitu daya kecambah $100 \%$, kecepatan berkcambah 1.43, muncul epikotil sebesar 10\%, tinggi tanaman sebesar $13.64 \mathrm{~cm}$ dan panjang akar $6.16 \mathrm{~cm}$.
\end{abstract}

Kata kunci: benih, kebiul, skarifikasi, stratifikasi. 


\section{PENDAHULUAN}

Indonesia menyimpan potensi hayati yang merupakan sumber bahan baku obatobatan yang telah lama digunakan oleh suku-suku tradisional di Indonesia. Indonesia memiliki luas kawasan lahan pertanian mencapai 120,35 juta hektar dan $80 \%$ adalah total jenis tumbuhan berkhasiat obat (Heriyanto, 2006). Kondisi wilayah hutan provinsi Bengkulu banyak di temukan berbagai jenis tumbuhan yang dimanfaatkan oleh masyarakat sebagai obat tradisional. Salah satu jenis tanaman yang digunakan sebagai obat oleh masyarakat adalah buah C. bonduc.

Kebiul merupakan tumbuhan berbiji tunggal, batangnya memanjang dan seluruh permukaan batang berduri. Biji kebiul banyak digunakan oleh masyarakat Bengkulu Selatan sebagai obat untuk pengobatan berbagai pernyakit seperti malaria, sakit kepala, kencing manis, batu ginjal dan batu empedu. Berdasarkan pengalaman masyarakat, pengobatan menggunakan biji $C$. bonduc ini mempunyai efek penyembuhan yang baik (Anggi, 2013).

Benih tumbuhan tropis sebagian besar tidak memiliki dormansi, ada juga beberapa diantaranya diketahui memiliki dormansi dan tidak mampu langsung berkecambah meskipun berada pada kondisi lingkungan yang mendukung. Dormansi dapat dinyatakan sebagai kondisi terjadinya hambatan perkecambahan yang disebabkan embrio mengalami belum matang dan beberapa kendala seperti kulit benih atau adanya suatu zat atau materi yang menutupi jaringan benih (Baskin dan Baskin, 2005). Penyebab dormansi yang sangat meluas adalah pada beberapa jenis tanaman benih yang memiliki organ tambahan berupa struktur penutup benih berkulit keras. Kulit benih yang keras ini biasanya menyebabkan dormansi melalui satu dari tiga cara, seperti kulit yang keras dapat menyebabkan impermeabel terhadap air, gas atau mungkin secara mekanik menekan perkembangan embrio (Leadem, 1997).

Jenis dari famili leguminosae menunjukkan dormansi fisik yang disebabkan oleh struktur morfologis dari kulit biji yang rumit. Pematahan dormansi benih berkulit keras dapat dilakukan dengan berbagai metode teknik perlakuan fisik, kimia, dan mekanis. Berbagai macam metode telah dikembangkan untuk mengatasi tipe dormansi ini, semua metode menggunakan prinsip yang sama yakni bagaimana caranya agar air dapat masuk dan melakukan proses imbibisi pada kulit benih (Coppelad, 1980). Perlakuan pemanasan yaitu dengan merendam benih ke dalam air panas pada suhu dan waktu yang berbeda, tujuannya adalah memberikan kesempatan kulit benih menjadi lunak sehingga kulit benih lebih mudah melakukan proses imbibisi, begitu juga terhadap waktu atau lama perendaman tujuannya adalah memberi kesempatan biji menyerap air dalam kondisi yang cukup untuk merangsang perkecambahan biji yang lebih lama kontak langsung dengan benih. Perendaman benih dengan waktu yang berbeda adalah untuk mengetahui waktu perendaman yang efektif dalam mengatasi dormansi. Perendaman benih dengan lama waktu yang berbeda-beda mampu melunakkan dan membuka pori-pori kulit benih yang keras (Nurshanti, 2013).

Perlakuan untuk mematahkan dormansi pada benih, harus diketahui terlebih dahulu macam dormansi dan penyebabnya pada benih. Ada berbagai cara perlakuan pendahuluan yang dapat diklasifikasikan yaitu pengurangan ketebalan kulit atau skrafikasi, perendaman dalam air, perlakuan dengan zat kimia, penyimpanan benih dalam kondisi lembab dengan suhu dingin dan hangat atau disebut stratifikasi berbagai perlakuan lain (Kartiko, 1986). Jika suhu udara meningkat atau menurun dan mengandung jumlah uap air yang sama, 
kelembapannya akan berubah. Misal, udara pada kelembapan tertentu $(70 \%)$ dipanaskan $\left(20^{\circ} \mathrm{C}\right.$ menjadi $\left.30^{\circ} \mathrm{C}\right)$, kelembapannya menurun (dalam contoh sampai $30^{\circ} \mathrm{C}$ ). Sebaliknya jika suhu udara menurun (pada malam hari), kelembapan akan meningkat. Jika kelembapan awal tinggi atau penurunan suhu cukup tinggi, udara dapat mencapai titik jenuh, sehingga kelembapan mencapai 100\% (Budi, 2006).

Air dalam benih cenderung dalam keadaan seimbang dengan kelembapan udara (RH) di sekitar benih. Jika udara kering dan benih lembab, air akan cenderung berpindah berlawanan arah sehingga benih menjadi lembab. Absorbsi dan desorbsi (pengeluaran) air dipengaruhi oleh benih atau ukuran buah, dan strruktur buah atau kulit benih. Benih berukuran kecil menyerap atau melepaskan air lebih cepat dari pada yang lebih besar karena luas permukaannya relatif besar di banding volumenya, dan jarak bagi perpindahan air lebih pendek. Anatomi benih akan menentukan seberapa cepat air dapat berpindah dari bagian dalam ke bagian luar selama proses pengeringan. Struktur yang tebal atau padat akan menghambat pergerakan air (Budi. 2006).

Perlakuan perendaman benih memungkinkan proses perkecambahan berlangsung lebih cepat sehingga kecambah lebih panjang dibandingkan dengan tanpa perendaman (Hanegave et al., 2011). Penggunaan air mendidih merupakan metode yang paling mudah (Soerodjotonojo, 1983). Hasil penelitian menunjukan bahwa perendaman di dalam air panas dengan suhu $80^{\circ} \mathrm{C}-100^{\circ} \mathrm{C}$ kemudian didiamkan selama 24 jam menunjukkan daya kecambah yang lebih tinggi (Khaerudin, 1994). Hasil penelitian Sugama (1991) dengan melukai benih aren disekitar embrio selebar kurang lebih $5 \mathrm{~mm}$ menghasilkan perkecambahan sebesar $60.67 \%$. Suzanti (1995) menyatakan bahwa kombinasi stratifikasi suhu $50^{\circ} \mathrm{C}$ dengan IAA $50 \mathrm{ppm}$ merupakan perlakuan terbaik dengan persentase perkecambahan benih aren sebesar 60. Hasil penelitian Saleh (2002) benih aren yang diberi perlakuan dengan teknik mengikis punggung benih menghasilkan nilai daya kecambah (DB) tertinggi hanya $50 \%$ - 55\%. Selanjutnya hasil penelitian Saleh (2003) juga menunjukkan bahwa benih aren yang diskarifikasi dengan kertas amplas dan dikombinasikan dengan perendaman dalam larutan KNO3 0.5\% selama 12, 24 dan 36 jam mempunyai nilai rataan daya kecambah (DB) sebesar 74.44\%. Perbedaan ini diduga karena teknik skarifikasi, sumber benih dan kondisi lingkungan perkecambahan yang berbeda.

Penyerapan air merupakan proses yang pertama kali terjadi pada perkecambahan benih, diikuti dengan pelunakan kulit benih, dan pengembangan benih. Penyerapan air ini dilakukan oleh kulit benih melalui peristiwa imbibisi dan osmosis yang prosesnya tidak memerlukan energi. Penyerapan air oleh embrio dan endosperm menyebabkan pembengkakkan dari kedua struktur, sehingga mendesak kulit benih yang sudah lunak sampai pecah dan memberikan ruang untuk keluarnya akar (Schmidt, 2002).

Penelitian ini bertujuan untuk mendapatkan metode yang terbaik untuk memecahkan dormansi benih kebiul.

\section{METODOLOGI}

Penelitian dilaksanakan pada bulan Desember 2015 sampai dengan Januari 2016, di Kelurahan Rawa Makmur, Kecamatan Muara Bangkahulu, Kota Bengkulu. Penelitian ini menggunakan Rancangan Acak Lengkap (RAL) faktor tunggal dengan kombinasi 11 perlakuan, terdiri dari : perendaman dalam air dengan suhu $30^{\circ} \mathrm{C}$ selama 0 jam (PD1), perendaman dalam air 
dengan suhu $300 \mathrm{C}$ selama 5 jam (PD2), perendaman dalam air dengan suhu $30^{\circ} \mathrm{C}$ selama 10 jam (PD3), perendaman dalam air dengan suhu $30^{\circ} \mathrm{C}$ selama 15 jam (PD4), perendaman dalam air panas dengan suhu $100^{\circ} \mathrm{C}$ selama 5 jam (PD5), perendaman dalam air panas dengan suhu awal $100^{\circ} \mathrm{C}$ selama 10 jam (PD6), perendaman dalam air panas dengan suhu awal $100^{\circ} \mathrm{C}$ selama 15 jam (PD7), stratifikasi hangat dengan kelembapan udara (RH) $100 \%$ dengan suhu 400C selama 5 hari (PD8), stratifikasi hangat dengan kelembapan udara $(\mathrm{RH})$ $100 \%$ dengan suhu $40^{\circ} \mathrm{C}$ selama 10 hari (PD9), stratifikasi hangat dengan kelembapan udara (RH) $100 \%$ dengan suhu $40^{\circ}$ C selama 15 hari (PD10), dan skarifikasi dengan pelukaan kulit (PD 11).

Dalam penelitian ini terdapat 11 perlakuan, masing-masing perlakuan diulang sebanyak lima kali, dalam setiap ulangan digunakan 10 butir biji kebiul (sampel), sehingga total keseluruhan yaitu 550 butir benih kebiul.

Benih kebiul di peroleh langsung dari daerah kota Manna Kabupaten Bengkulu Selatan. Benih yang dipilih adalah benih utuh, tidak cacat, bernas, memiliki warna dan bentuk yang seragam.

Sebelum benih dikecambahkan terlebih dahulu diberi perlakuan sesuai dengan metode perlakuan yang telah ditentukan. Pematahan dormansi dengan metode perendaman, dilakukan dengan cara merendam benih kebiul didalam air dengan suhu yang berbeda $\left(30^{\circ} \mathrm{C}\right.$ dan $\left.100^{\circ} \mathrm{C}\right)$. Suhu air diukur menggunakan alat thermometer dan menggunakan wadah berukuran sedang sebagai tempat merendam benih dengan waktu yang berbeda selama ( 0 jam, 5 jam, 10 jam, dan 15 jam). Pematahan dormansi metode penderaan dengan cara membuat media pasir dengan kondisi lembab. Benih kebiul dimasukkan kedalam media pasir, kemudian dibungkus plastik dengan tujuan untuk menjaga kelembapan 100\%, selanjutnya mengoven. Nampan beserta isinya dimasukkan kedalam oven dengan suhu $40^{\circ} \mathrm{C}$ selama waktu yang berbeda ( 5 hari, 10 hari, 15 hari). Untuk mengukur kelembaban menggunakan alat thermohygrometer. Pematahan dormansi juga dilakukan dengan pelukaan pada kulit benih.

Media yang digunakan pada penelitian ini yaitu tanah topsoil yang di campur pasir yang sudah disterilisasi dengan cara mengukus didalam dandang selama dua jam dengan perbandingan (volume) 1:1, kemudian diaduk rata mengggunakan cangkul dan di masukan ke dalam nampan berukuran $40 \mathrm{~cm}$ x $30 \mathrm{~cm}$ x $12 \mathrm{~cm}$.

Setelah benih diberi perlakuan, benih disemai selama satu bulan di dalam nampan berukuran $40 \mathrm{~cm} \times 30 \mathrm{~cm} \times 12 \mathrm{~cm}$ yang berisi media tanah campur pasir sungai.

Pemeliharan yang di lakukan pada penelitian ini yaitu melakukan penyiraman pada pagi dan sore hari, agar kondisi media tetap lembab, terdapat gulma di persemaian dicabut secara manual dengan tujuan agar pertumbuhan perkcembahan benih tidak terganggu.

Pengamatan dilakukan setelah biji berkecambah berumur empat minggu, dengan menampakan ciri daun plumula sudah muncul. Adapun variabel yang diamati :

\section{a. Daya Kecambah (\%)}

Persentase perkecambahan dihitung dengan menggunakan rumus

$$
\text { Daya Kecambah }=\frac{\begin{array}{c}
\text { Jumlah benih yang berkecam- } \\
\text { bah x } 100
\end{array}}{\begin{array}{c}
\text { Jumlah benih yang dikecam- } \\
\text { bahkan }
\end{array}}
$$

b. Indeks Vigor benih (hari) : Menurut Coleland 1977 (dalam Kartasapoetra, 1986) mengemukakan bahwa kecepatan berkecambah digunakan sebagai penilaian vigor benih dirumuskan sebagai berikut : 


$$
I V=\frac{G 1}{D 1}+\frac{G 2}{D 2}+\frac{G 3}{D 3} \ldots \ldots \ldots+\frac{G n}{D n}
$$

Keterangan :

IV: Indeks Vigor

$\mathrm{G}$ : Jumlah benih berkecambah pada hari tertentu

D : Waktu yang bersesuaian dengan jumlah tersebut (hari)

$\mathrm{n}$ : Jumlah hari pada perhitungan terakhir

c. Jumlah muncul epikotil (buah) pengukuran dengan cara mengakumulasi terbentuknya epikotil yang ditandai dengan menampakan ciri muncul daun plumula sebesar $1 \mathrm{~cm}$ selama satu bulan.

d. Tinggi tanaman $(\mathrm{cm})$ : tinggi tanaman diamati setelah berumur satu minggu setelah perkecambahan, pengamatan dilakukan satu minggu sekali selama penelitian. Tinggi tanaman di ukur dari pangkal batang hingga ke titik tumbuh tanaman.

e. Panjang akar : Panjang akar di ukur pada akhir penelitian menggunakan mistar (skala cm). panjang akar di ukur dari pangkal batang sampai akar terpanjang.

Data yang tidak homogen terlebih dahulu ditransformasi dengan rumus SQRT (Square root) dan data yang diperoleh dianalisis dengan menggunakan analisis keragaman (uji F) pada taraf uji 5\% dan pada perlakuan yang menunjukkan perbedaan yang nyata dilanjutkan dengan uji lanjut BNT dengan satu faktor pada taraf 5\%.

\section{HASIL DAN PEMBAHASAN}

Berdasarkan hasil analisis keragaman menunjukan bahwa perlakuan skarifikasi dan stratifikasi berpengaruh nyata terhadap variabel persentase daya kecambah, indeks vigor benih, saat muncul epikotil (hari), tinggi tanaman $(\mathrm{cm})$, dan tidak berpengaruh nyata terhadap variabel panjang akar $(\mathrm{cm})$. Hasil analisis beberapa variabel yang di uji dapat dilihat pada Tabel 1 .

Hasil pengujian pada beberapa variabel (Tabel 1) nilai keragaman menunjukan berbeda sangat nyata. Artinya pada perlakuan yang diaplikasikan melalui pelukaan kulit benih memberikan pengaruh berbeda pada semua variabel yang diuji.

Untuk mengetahui perbedaan hasil dari analisis masing-masing variabel yang diuji disajikan pada Tabel 2.

\section{Daya Kecambah}

Hasil analisis uji lanjut BNT pada perlakuan PD 11 berupa peelukaan kulit benih merupakan perlakuan yang terbaik terhadap variabel daya kecambah (100\%), sedangkan perlakuan lainnya PD1 sampai dengan PD10 menghasilkan daya kecambah antara $0-1 \%$ jauh lebih rendah dan berbeda dengan PD11. Hasil penelitian Nurahmi et al. (2010), menyatakan bahwa dengan memberikan perlakuan skarifikasi berupa pelukaan pada kulit benih pala dapat memberikan pengaruh nyata terhadap peubah daya kecambah dan kecepatan berkecambah.

Perlakuan skarifikasi yaitu dengan cara pelukaan kulit benih mengakibatkan faktor penghambat fisiologis kulit benih menjadi berkurang sehingga air dan oksigen dapat dengan lebih mudah berimbibisi kedalam benih, sehingga dapat mempercepat proses perkecambahan dan meningkatkan daya perkecambahan.

Menurut hasil penelitian Dharma (2015), perlakuan skarifikasi penuh pada benih pala dengan pengamplasan memberikan nilai daya berkecambah tertinggi yaitu $96.66 \%$ dan berbeda nyata dengan perlakuan tanpa skarifikasi yang hanya memberikan daya berkecambah $80.00 \%$. Menurut Kuswanto (1996), proses awal yang terjadi dalam perkecambahan adalah proses im- 
Tabel 1. Hasil analisis keragaman perlakuan skarifikasi (fisik) dan stratifikasi (fisiologis) pematahan dormansi benih kebiul terhadap beberapa variabel.

\begin{tabular}{lrc}
\hline \multicolumn{1}{c}{ Variabel } & \multicolumn{1}{c}{ F hit } & F-Tabel \\
\hline Daya Kecambah (\%) & $10.18^{* *}$ & 2.75 \\
Indeks Vigor Benih & $426.08^{* *}$ & 2.75 \\
Jumlah Muncul Epikotil (buah) & $13.57^{* *}$ & 2.75 \\
Tinggi Tanaman (cm) & $6.25^{* *}$ & 2.75 \\
Panjang Akar (cm) & $24.55^{* *}$ & 2.75 \\
\hline
\end{tabular}

Ket: $* *=$ sangat berbeda nyata pada $\alpha 5 \%$, ns = tidak berbeda nyata pada taraf $\alpha 1 \%$.

Tabel 2. Hasil uji lanjut BNT beberapa variabel yang diuji pada masing-masing perlakuan metode pematahan dormansi

\begin{tabular}{|c|c|c|c|c|c|c|}
\hline \multirow[b]{2}{*}{ Perlakuan } & \multicolumn{6}{|c|}{ Variabel } \\
\hline & Suhu/waktu & DK $(\%)$ & IVB & JME (buah) & $\mathrm{TT}(\mathrm{cm})$ & $\begin{array}{c}\text { Panjang } \\
\text { Akar }(\mathrm{cm})\end{array}$ \\
\hline PD1 & $30^{0} \mathrm{C} / 0$ jam & $4 b$ & $0.002 b$ & $0.4 b$ & $2.70 \mathrm{~b}$ & $0.50 \mathrm{~b}$ \\
\hline PD2 & $30^{0} \mathrm{C} / 5$ jam & $2 b$ & $0.006 b$ & $0.2 b$ & $1.82 \mathrm{~b}$ & $0.22 b$ \\
\hline PD3 & $30^{\circ} \mathrm{C} / 10$ jam & $2 b$ & $0.006 \mathrm{~b}$ & $0.2 b$ & $1.70 \mathrm{~b}$ & $0.18 b$ \\
\hline PD4 & $30^{\circ} \mathrm{C} / 15 \mathrm{jam}$ & $0 \mathrm{~b}$ & $0.000 \mathrm{~b}$ & $0.0 \mathrm{~b}$ & $0.00 \mathrm{~b}$ & $0.00 \mathrm{~b}$ \\
\hline PD5 & $100^{\circ} \mathrm{C} / 5$ jam & $0 \mathrm{~b}$ & $0.000 \mathrm{~b}$ & $0.0 \mathrm{~b}$ & $0.00 \mathrm{~b}$ & $0.00 \mathrm{~b}$ \\
\hline PD6 & $100^{\circ} \mathrm{C} / 10 \mathrm{jam}$ & $2 b$ & $0.006 \mathrm{~b}$ & $0.2 b$ & $0.90 \mathrm{~b}$ & $0.18 b$ \\
\hline PD7 & $100^{\circ} \mathrm{C} / 15 \mathrm{jam}$ & $2 b$ & $0.008 b$ & $0.2 b$ & $2.00 \mathrm{~b}$ & $0.26 b$ \\
\hline PD8 & $\begin{array}{l}\text { RH (100\%) } \\
40^{\circ} \mathrm{C} / 5 \text { hari }\end{array}$ & $2 b$ & $0.008 b$ & $0.2 b$ & $1.10 \mathrm{~b}$ & $0.18 b$ \\
\hline PD9 & $\begin{array}{c}\text { RH }(100 \%) \\
40^{\circ} \mathrm{C} / 10 \text { hari }\end{array}$ & $4 b$ & $0.001 \mathrm{~b}$ & $0.4 b$ & $3.90 \mathrm{~b}$ & $0.50 \mathrm{~b}$ \\
\hline PD10 & $\begin{array}{l}\text { RH }(100 \%) \\
40^{\circ} \mathrm{C} / 15 \text { hari }\end{array}$ & $2 b$ & $0.001 \mathrm{~b}$ & $0.2 b$ & $0.90 \mathrm{~b}$ & $0.14 b$ \\
\hline PD11 & $\begin{array}{l}\text { Pelukaan kulit } \\
\text { benih }\end{array}$ & $100 \mathrm{a}$ & $1.430 \mathrm{a}$ & $10.0 \mathrm{a}$ & $16.78 \mathrm{a}$ & $6.16 \mathrm{a}$ \\
\hline
\end{tabular}

Ket: angka-angka yang diikuti oleh huruf yang sama pada kolom yang sama menunjukan berbeda tidak nyata pada taraf $5 \% . \mathrm{DK}=$ daya kecambah, $\mathrm{IVB}=$ indeks vigor benih, $\mathrm{JME}=$ jumlah muncul epikotil, $\mathrm{TT}=$ tinggi tanaman, $\mathrm{PA}=$ panjang akar.

bibisi, yaitu masuknya air ke dalam benih sehingga kadar air didalam benih mencapai persentase tertentu $(50 \%-60 \%)$.

\section{Indeks Vigor Benih}

Hasil analisis uji BNT pada setiap taraf perlakuan dari PD1 hingga PD10 menunjukkan indeks kecepatan berkecambah yang lebih rendah $(0-0.8)$ dan berbeda dibandingkan dengan perlakuan PD11 sebesar 1,43 Artinya dengan berbagai taraf perlakuan belum mampu meningkatkan kecepatan benih kebiul untuk berkecam- bah secara optimal. Hal ini disebabkan oleh perlakuan skarifikasi penuh pada kulit benih sehingga kulit benih menjadi lebih tipis dan bagian penghambat proses imbibisi sudah tidak ada lagi, dengan demikian kulit benih akan mudah dilalui oleh air dan oksigen, sehingga proses imbibisi yang diikuti proses perkecambahan embrio lebih cepat dan lebih mudah menembus cangkang benih. Indeks vigor sangat dipengaruhi oleh faktor kematangan benih, kecepatan imbibisi, air, udara, temperatur yang mendukung. Pada penelitian ini kece- 
patan berkecambah hanya dapat dipengaruhi oleh faktor perrlakuan kulit benih saja. Karena yang digunakan dalam penelitian ini kondisinya seragam baik warna, ukuran maupun tingkat kematangan buah (kematangan biji).

\section{Jumlah Muncul Epikotil}

Proses pembentukan setelah proses perkecambahan adalah proses pembentukan epikotil. Epikotil muncul jika seluruh proses perkecambahan telah berakhir. Dari hasil perkecambahan menunjukkan pada perlakuan dengan pelukaan kulit benih lebih awal muncul epikotil dengan jumlah terbanyak 10 buah, sedangkan pada perlakuan PD4 dan PD5 jumlah epikotil yang muncul 0 (tidak ada epikotil), artinya dengan pelukaan kulit benih (PD11) mampu meningkatkan pemecahan dormansi kulit benih kebiul. Hal tersebut berkorelasi positif dengan variabel lainnya yaitu pada perlakuan PD11 sangat dipengaruhi oleh faktor indeks benih. Semakin tinggi vigor benih menunjukkan benih semakin cepat berkecambah yang diikuti dengan munculnya epikotil. Pada perlakuan PD4 dan PD5 menunjukkan indeks vigor benih nol artinya benih yang diberi perlakuan tiak ada respon untuk berkecambah.

Biji-biji yang berkulit keras akan menjadi permeabel terhadap air bila bijibiji tersebut dikikir. Salah satu efek pemberian perlakuan skarifikasi pelukaan kulit benih. Perlakuan skarifikasi cenderung lebih cepat pertumbuhannya dibandingkan dengan perlakuan lainnya, hal ini disebabkan karena kulit benih yang diberi perlakuan skarifikasi berupa pelukaan kulit menjadi lunak karena lapisan kulit luar pada benih kebiul terbuka sehingga air dan oksigen dapat masuk dengan mudah pada benih dengan cukup baik dan pada calon plumula akan tumbuh cepat dan mencari unsur hara sebagai untuk proses perkecambahan (Sutopo, 2004).

\section{Tinggi Tanaman}

Hasil rerataan tertinggi tanaman dengan uji lanjut BNT menunjukkan berbeda sangat nyata. Perlakuan skarifikasi berupa pelukaan kulit benih menghasilkan tinggi tanaman tertinggi dengan rata-rata 16.78 cm (Tabel 2). Pertumbuhan benih kebiul akan lebih cepat dengan diberikan perlakuan skarifikasi berupa pelukaan kulit pada benih, karena kulit benih kebiul ini memiliki kulit yang tebal sehingga sulit untuk ditembus oleh air dan oksigen ke dalam benih. Perlakuan pematahan dormansi berupa pelukaan kulit benih pada penelitian ini memberikan pengaruh yang baik untuk perkecambahan benih dengan pertumbuhan yang cepat. Pertumbuhan merupakan salah satu aspek perkembangan tanaman. Perkembangan adalah perubahan tertinggi secara keseluruhan baik kuantitatif maupun kualitatif selama siklus hidup tumbuhan (Tohari, 2002).

Metode perlakuan pematahan dormansi 4 (PD4) pada suhu $30^{\circ} \mathrm{C}$ selama 15 jam dan pematahan dormansi 5 (PD5) pada suhu $100 \%$ selama 5 jam belum mampu memecahkan dormansi pada benih kebiul (benih tidak berkecambah). Hal tersebut disebabkan dengan kemungkinan suhu dan waktu lama perendaman belum optimum, sehingga kulit benih tidak permeabel terhadap air dan oksigen. Pematahan dormansi 11 (PD11) rata-rata tinggi tanaman (16.78 $\mathrm{cm})$ lebih baik dibandingkan dengan pematahan dormansi lainnya terhadap tinggi tanaman, hal tersebut dapat dipengaruhi oleh tingkat indeks vigor yang tinggi, saat muncul epikotil lebih awal, dengan demikian proses pertumbuhan tinggi lama akan menjadi lebih cepat pula.

\section{Panjang Akar}

Perlakuan pematahan dormansi menunjukan pengaruh berbeda nyata terhadap variabel panjang akar pada perlakuan pelukaan kulit benih kebiul. Benih kebiul 
yang diberi perlakuan pelukaan kulit memiliki panjang akar dengan rataan mencapai $6,16 \mathrm{~cm}$ (Tabel 2). Hasil ini sama dengan perlakuan lainnya, kecuali pada perlakuan suhu awal $30^{\circ} \mathrm{C}$ selama 15 jam (PD4) dan suhu 100\% selama 5 jam (PD5) benih sama sekali tidak berkecambah. Hal tersebut disebabkan benih kebiul belum menunjukkan berbeda uji nyata karena organ akar berperan sebagai pengabsorbsi makanan dan air. Pada penelitian ini diduga proses pembelahan dan perpanjangan sel meristem pada akar lebih lambat dibandingkan dengan kecepatan panjangnya sel pada organ batang (epikotil) begitu juga lama pengamatan sangat terbatas (selama 30 hari) dengan pertimbangan daya kecambah pada metode perlakuan tertinggi sudah mencapai $100 \%$.

\section{KESIMPULAN DAN SARAN}

\section{Kesimpulan}

Metode perlakuan pematahan dormansi benih yang memberikan pengaruh terbaik adalah dengan metode perlakuan pelukaan kulit benih PD11 terhadap semua variabel daya kecambah $100 \%$, Indeks Vigor benih 1.43, jumlah epikotil muncul sebesar 10, tinggi tanaman sebesar $16.78 \mathrm{~cm}$, panjang akar $6.16 \mathrm{~cm}$.

\section{Saran}

Perlu dilakukan penelitian lanjut pada metode yang sama dengan tingkat suhu yang sama dan waktu perendaman yang lebih lama.

\section{DAFTAR PUSTAKA}

Anggi, R. P. 2013. Elektroforesis dan uji hemaglutinasi lektin biji Kebiul pada darah golongan ABO dan implementasi sebagai model pembelajaran audio-visual untuk meningkatkan hasil belajar kimia. Tesis. Universitas Bengkulu. Bengkulu. Hal 8-11. (tidak dipublikasikan)

Baskin, C.C. and Baskin. J.M. 2005. Seed Dormancy in Trees of Climax Tropical Vegetation Types. Tropical Ecology 46(1): 17-28.

Budi, U. 2006. Ekologi Benih. Universitas Sumatra Utara. Sumatra Utara. Hal 18-20.

Coppelad. 1980. Principles of Seed Science and Technology. Burgess Publ. co. Minneapolis,Minnesota.Hal-7.

Dharma. I. P. E. Samudin. S.S., Adrianton. 2015. Perkecambahan Benih Pala (Myristica Fragrans Houtt.) Dengan Metode Skarifikasi Dan Perendaman Zpt Alami. Fakultas Pertanian Universitas Tadulako. Palu. Vol. (2) : $158-167$.

Doran, J. C., Turnbull, J.W., Bolland, J. D. 1983. Handbook on seed of dryzone acacias. Aguide for collecting, extracting, cleaning, and stering the seed and for treatment topromote germination of dry-zone acacias. FAO Rome.Hal-5.

Ginting, D. 1979. Bercocok Tanam Kelapa Sawit (Elaies guineensis Jacq) dan Pengolahan Hasilnya. Sekolah Perkebunan Menengah Atas (SPbMA) Medan. hal.201

Hanegave, A.S., Hunye. R., H.L. Nadaf, N.K. Biradarpatil, and D.S. Uppar. 2011. Effect of seed priming on seed quality of maize. Karnataka Journal Agric. Sci. 24(2): 237-238.

Harjadi, S. S. 1986. Pengantar Agronomi. Gramedia. Jakarta. 210 hal.

Heriyanto, N. M. 2006. Keanekaragaman jenis pohon yang berpotensi obat di 
taman nasional meru betiri, Jawa Timur. Badan Penelitian dan Pengembangan Kehutanan. Departemen Kehutanan. Bogor.

Kamil, J. 1986. Teknologi Benih 1. Angkasa Raya. Padang.2. Hal. 219

Khaerudin. 1994. Pembibitan Tanaman HT. Penebar Swadaya. Jakarta.

Kartasapoetra, A. G. 1986. Teknik Benih,Pengelolaan Benih dan TuntunanPraktikum. Bina Aksara. Jakarta.

Kartiko, H. D. P. 1986. Pengaruh beberapa cara ekstraksi dan perlakuan pendahuluan terhadap daya berkecambah benih Rotan Manau (Calamus manna MIQ). Balai Teknologi Perbenihan. Bogor. 2:(1) 1-11.

Kuswanto H. 1996. Dasar-dasar Teknologi Produksi dan Sertifikasi Benih. Edisi ke-1. ANDI. Yogyakarta. Hlm 190.

Leadem, C. L. 1997. Dormancy-Unlocking Seed Secret. In : Landis, T. D., Thomson, J. R. Tech. Coords. National Proceedings, Forest and Conservation Nursery Association, Gen. Tech. Rep. PNW-G TR-419. Portland, OR: U. S. Departement Of Agriculture, Forest Service, Pacific Northwest Research Station. 1:(1). 15-23.

Morris, E.C. 2000. Germination response of seven eastAustralian Grevillea species (Proteaceae) tosmoke, heat exposure and scarification. Aust. J.Bot. 48:179-189.

Nurahmi, Erida., Agam Ihsan Herari., dan Afriansyah. 2010. Viabilitas Benih Pala (Myristica Fragrans HOUTT) pada Beberapa Tingkat Skarifikasi dan Konsentrasi Air Kelapa Muda. Unsyah Aceh. Agrista 14(2): 51-55.

Nurshanti, D. F. 2013. Tanggap perkecambahan benih palem ekor tupai
(Wodyetia bifurcate) terhadap lama perendaman dalam air. Jurnal Ilmiah AGRIBA. 2(9): 216-224.

Rahardjo, P. 2002.Beberapa Cara yang Perlu Dalam Perkecambahan Kopi, Sub Penelitian Budidaya Perkebunan Kopi. Bogor. 13-15p.

Sadjad, S. 1980. Panduan pembininaan mutu benih tanaman kehutanan di Indonesia.PPPK dan IPB. Bogor.1:(1).15-23.

Sahupala, A. 2007. Teknologi Benih. Fakultas Pertanian. Universitas Pattimura. Maluku.

Sugama. 1991. Pemecahan dormansi benih serta pengaruh media dan naungan terhadap pertumbuhan bibit enau (Arenga pinnata (Wurmb.) Merr.). Skripsi Jurusan Budidaya Pertanian. Fakultas Pertanian. Institut PertanianBogor. Bogor. (Tidak dipublikasikan).

Saleh, M. S. 2002. Perlakuan fisik dan kalium nitrat untuk mempercepat perkecambahan benih aren dan pengaruhnya terhadap pertumbuhan kecambah. Agroland 9 (4):326-330.

Saleh, M. S.2003. Peningkatan kecepatan berkecambah benih aren yang diberi perlakuan fisik dan lama perendaman KNO3. Agroland (suplemen) 52-57.

Schmidt, L. 2000. Pedoman Penanganan BenihTanaman Hutan Tropis dan Subtropis. Diterjemahkan oleh Direktorat Jendral Rehabilitasi Lahan dan Perhutanan Sosial Departemen Kehutanan. PT Gramedia. Jakarta. $530 \mathrm{hlm}$.

Schmidth, L. 2002. Pedoman Penanganan Benih Tanaman Hutan Tropis dan Subtropis. Jakarta: Direktorat Jendral Rehabilitasi Lahan dan Perhutanan Sosial Departemen Kehutanan. Hal-6. 
Schmidt, L. 2002. Pedoman Penanganan Benih Tanaman Hutan Tropis dan Sub Tropis (Terjemahan) Dr. Mohammad Na'iem. Bandung. Hal-6.

Sudikno, T Sudarti. 1991. Beberapa usaha untuk mempercepatperkecambahan biji melinjo (Gnetum gnemon L.). Agric. Sci. 4(6):257-272.

Sumardi. 1990. Pengaruh Temperatur Awal Air Perendaman dan Lama Perendaman Benih Terhadap Petumbuhan Bibit Karet (Havea brasilienssis Muell-Arg) Laporan Penelitian. Bengkulu. 73 hal (tidak dipublikasikan).

Sutopo , L. 2004. Teknologi Benih. edisi Revisi. Cetakan ke-6.PT Raja Grafindo. Jakarta.

Sutopo, L. 2004. Teknologi Benih. CV Rajawali. Jakarta.
Suzanti, G. 1995. Pengaruh suhu dan ZPT terhadap pematahan dormansi pada dua stadium kemasakan benih serta pengaruh pemupukan terhadap pertumbuhan bibit aren (Arenga pinnata (Wurmb.) Merr.). Skripsi Jurusan Budidaya Pertanian. Fakultas Pertanian. Institut Pertanian Bogor. Bogor. 51 hal. (Tidak dipublikasikan).

Soerodjotonojo. 1993. Membina Usaha Perkebunan. Balai Pustaka. Jakarta.

Tohari, 2002. Sistem Pertanaman Ganda: SuatuStrategi Agronomi Adaptif Daerah TropikBasah. Pidato Pengukuhan Guru Besar Faperta. UGM

Widyawati. 2009. Permeabilitas dan perkecambahan benih aren (Arenga pinnata) (Wurmb.) Merr.). Jurnal Agronomi Indonesia 37 (2) : $152-158$. 